\title{
APPLICATION OF SMALL AND MICRO COGENERATION UNITS
}

\author{
Milan R. Radosavljević \\ University of Kragujevac, Faculty of Engineering, \\ Department for Energy and Process Engineering, \\ Kragujevac, Republic of Serbia, \\ e-mail: milancer27@gmail.com, \\ ORCID iD: (i)http://orcid.org/0000-0003-4228-8850
}

http://dx.doi.org/10.5937/vojtehg66-7309

FIELD: Chemical Technology

ARTICLE TYPE: Professional Paper

ARTICLE LANGUAGE: English

Abstract:

By 1973, low oil prices had provided the production of relatively cheap electricity. A sudden increase in gas prices caused a need for developing energy technologies as well as a need for increasing the efficiency of power plants. At the same time, increased environmental awareness as well as the awareness of the growing scarcity of energy sources required greater attention to preserving the environment and the existing resources, so small and micro cogeneration plants become efficient and competitive energy producers. The United States and Canada are currently lagging behind Europe and Japan in relation to the development of micro cogeneration units, partly because of differences in heating systems, energy prices and political framework. In accordance with the Kyoto Protocol, Japan is obliged to reduce its global warming i.e. gas emissions by $6 \%$ of the 1990 level. However, CO2 emissions continue to grow, which means that it is currently estimated that Japan must reduce emissions by $14 \%$ to meet the goal. Japan should promote all possible ways to effectively reduce $\mathrm{CO} 2$ emissions. In this regard, it continues to give support to micro cogeneration marketing, especially for models suitable for residential buildings. It is estimated that, in the next few years, energy production by cogeneration will reach $75 \%$ of the total production at the European level. In Italy, ecological energy makes $30 \%$ of the total consumption, in the Netherlands 33\%, and in Denmark and the UK it is almost completely present.

Key words: micro cogeneration, small cogeneration.

\section{Introduction}

Cogeneration is the process of a combined production of heat and electricity. The reasons for the application of CHP plants are economic in nature and originate in energy efficiency. In practice, the maximum 
degree of efficiency that can be achieved when it comes to electrical power is $40 \%$, and the rest of the useful energy is used for heating (Pehnt et al, 2006).

Decentralised installations for a combined production of heat and electricity can achieve a total degree of efficiency of $90 \%$. There has been a significant increase in a total degree of efficiency in relation to the degree of usefulness of $36 \%$ achieved by centralized condensation plants for electricity production (Despotović \& Babić, 2007).

Achieving sustainable development in the energy sector requires specific quality changes to be undertaken. This includes limiting the use of resources of fossil fuels and reducing emissions by $50-80 \%$ by 2050 , i.e. their adverse impact on climate change.

Directive 2004/8/EC obliges the Member States to carry out an analysis of the potential of cogeneration efficiency in their country and to establish a system of incentives to apply cogeneration. For either small $(<1 \mathrm{MWe})$ or micro $(<50 \mathrm{kWe})$ cogeneration installations, the directive states that it is necessary to ensure a high level of efficiency for each new capacity. The directive clarifies that high efficiency must provide primary energy saving of at least $10 \%$ compared to separate production of heat and electricity.

\section{Small and micro cogeneration plants}

Today, there are several technologies used in cogeneration plants such as piston engines, gas turbines, Stirling engines and fuel cells. Advances in technology (Rosato \& Sibilio, 2013, pp. 478-491) as well as a general trend towards smaller manufacturing units have led to an increased interest in small cogeneration units, in hope that they will be able to provide electricity and thermal energy for individual objects (de Paepe et al, 2006, pp. 3435-3446).

Small cogeneration plants driven by gas engines with internal combustion are fully adapted to the needs of consumers; they use $88 \%$ of natural gas energy, thus providing cheaper and better energy, as well as long-term planning of costs, all of which is in accordance with the strictest European environmental standards (Said et al, 2005, pp. 259262).

The EU directive on cogeneration defines micro cogeneration as a unit with a maximum capacity smaller than $50 \mathrm{kWe}$, while in Germany, micro cogeneration systems are those under $15 \mathrm{kWe}$ for the following reasons: these systems are clearly intended for use in family homes, apartment buildings, small businesses, or hotels (Pehnt et al, 2006). 


\section{Examples of commercially available CHP units}

CHP units with piston engines are commercially available and are manufactured in many different companies around the world. The market leader is the German company Senertec. A Senertec model known as Dachs generates $5.5 \mathrm{Kwe}$ and $14 \mathrm{~kW}$ of thermal energy (Figure 1) (Cummins Inc, 2014).

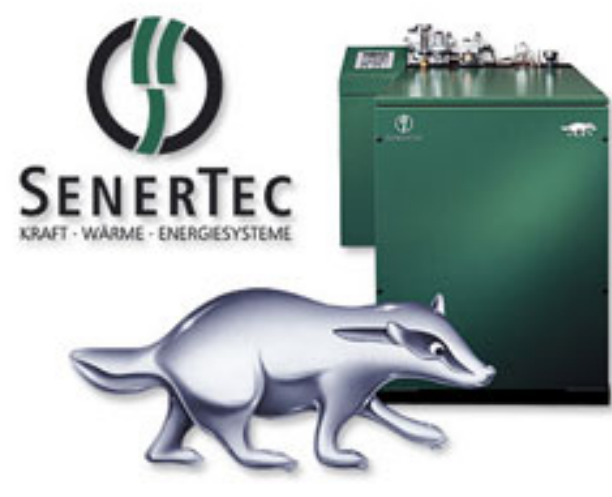

Figure 1 - Senertec Dachs

Puc. 1 - Senertec Dachs

Слика 1 - Senertec Dachs

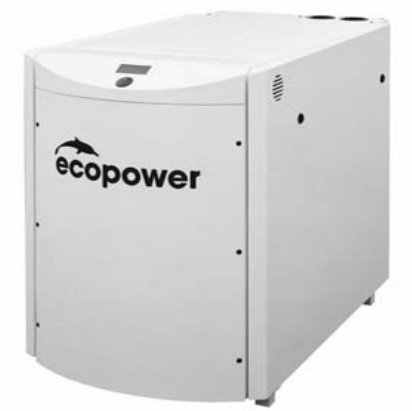

Figure 2 - PowerPlus Ecopower

Puc. 2 - PowerPlus Ecopower

Слика 2 - PowerPlus Ecopower

Other companies that produce micro cogeneration units are Power Plus with a $4.7 \mathrm{kWe}$ Ecopower module which is able to modulate the capacity of $5 \mathrm{kWe}$ and $15 \mathrm{kWe}$, and Vector-based CoGen (US), which uses a Kawasaki engine for combustion. According to the product specification, the Vector CoGen unit reached an electrical efficiency of 
about 28 to 34 percent and an overall energy efficiency between 70 and $79 \%$.

In Japan, YANMAR, Sanyo and AISIN companies have also developed technology with piston engines to produce micro cogeneration units.

There is an interesting development of a Honda small $1 \mathrm{kWe}$ system for family houses called Ecowill (Figure 3). This Honda's cogeneration unit uses the GE160V, the world's smallest engine on natural gas. The system is based on one Otto engine and a system for the control and reduction of NOx emission concentration (Pehnt et al, 2006).

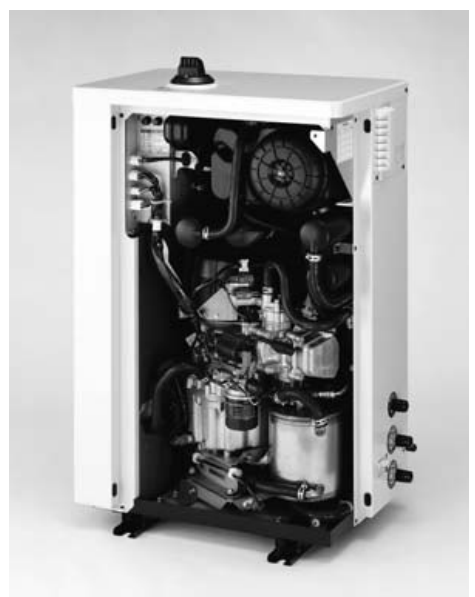

Figure 3-Honda Ecowill

Puc. 3 - Honda Ecowill

Слика 3 - Honda Ecowill

One of the technologies suitable for cogeneration is the application of gas turbines or micro-turbines. One of the advantages of using turbines in relation to modern engines with internal combustion is extremely low emission of harmful gases. They can use both liquid and gaseous fuel, i.e. fossil or renewable energy sources. Microturbine capacity ranges from $30 \mathrm{~kW}$ to $350 \mathrm{~kW}$.

It is also possible to use biogas and waste gases (gases of refineries, industry) as fuel. However, the biogas chemical composition affects the operation of turbines - biogas must meet requirements i.e. percentage content of the composition of the gases that make up biogas must be adequate.

The Kawasaki company offers gas turbines from 0.61 MWe (Figure 4) which emit less than 3 ppm NOx. 


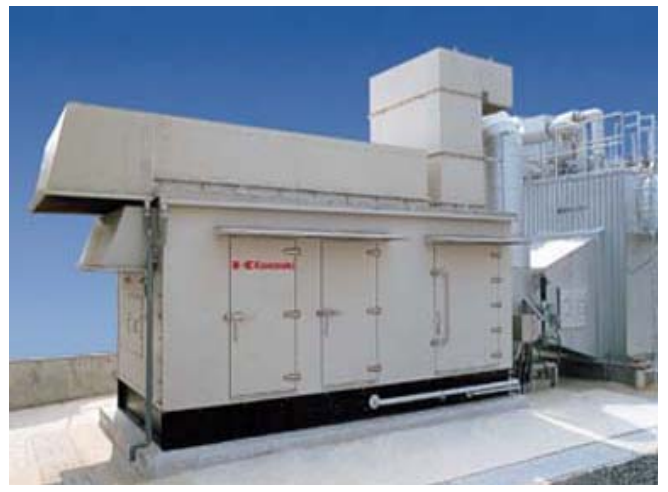

Figure 4-KAWASAKI Gas Turbine Europe Puc. 4-KAWASAKI Gas Turbine Europe Слика 4 - KAWASAKI Gas Turbine Europe

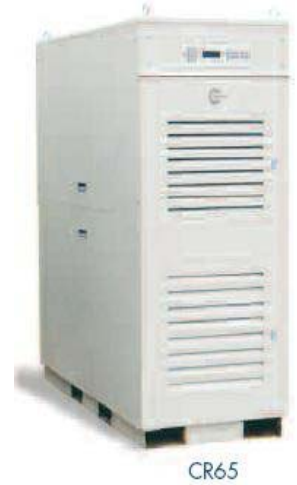

Figure 5-CAPSTONE Turbines PUc. 5-CAPSTONE Turbines

Слика 5 - CAPSTONE Turbines

The CAPSTONE Turbine (USA) is a microturbine with a capacity of $65 \mathrm{~kW}$, which can use biogas as fuel and can reach $29 \%$ of electrical efficiency and $62 \%$ of total efficiency (Figure 5 ).

Stirling engines are still in the testing phase, but there are also some commercial ones that could soon be in serial production: e.g. the WhisperTech company (New Zealand) is developing Stirling engines called WhisperGen, with a capacity of up to $1.2 \mathrm{kWe}$ and $8 \mathrm{~kW}$ of heat energy. $1 \mathrm{kWe}$.

The Swiss company $\mathrm{GmbH}$ focuses on making Stirling engines of 1. 
As for systems with a capacity exceeding $1 \mathrm{kWe}$, the German companies Solo (Figure 7), Mayer and the CLA and Sunmachine (Figure 6 ) are involved in the development of Stirling engines.

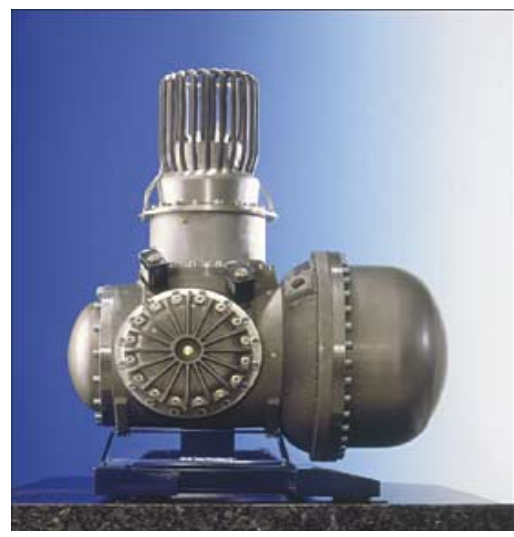

Figure 6 - Sunmachine Puc. 6 - Sunmachine (Stirling двигатель) Слика 6 - Sunmachine (Stirling мотор)

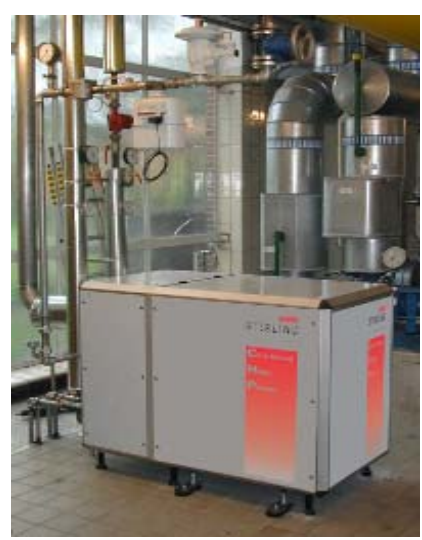

Figure 7 - Solo

Puc. 7 - Solo (Stirling двигатель)

Слика 7 - Solo (Stirling мотор)

The advantage of using these systems is that they can use biomass (Alanne et al, 2014, pp. 1-10), solar power, wind or fossil fuels as a source of energy. This flexibility and high engine efficiency mean that these systems can be used for a long term period. In addition, it is necessary to reduce the cost of these systems to make them commercially competitive with other cogeneration technologies. A typical 
CHP units with a $7.5 \mathrm{kWe}$ Stirling engine costs approximately $€ 2600 / \mathrm{kWe}$.

KWB, from Austria, has developed a Stirling engine using pellet as a heat source. Its capacity is $1 \mathrm{kWe}$.

Dutch Enatec (Figure 8) is developing a Stirling engine with a capacity of $1 \mathrm{kWe}(4-35 \mathrm{kWt})$. The Enatec company is concentrated on the use of fossil fuels for Stirling units.

Microgen (Figure 9) from the UK has developed one of the first small $\mathrm{CHP}$ units for individual homes. The unit is small and quiet enough so that it can be mounted in the kitchen. It has a capacity of 1.1 and $\mathrm{kWe}$ $15-36 \mathrm{kWt}$. It is designed to use natural gas as fuel, and an oil version is in preparation. The overall efficiency is rated at $90 \%$.

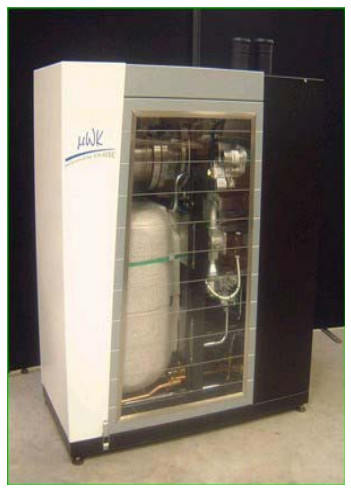

Figure 8-ENATEC

PUC. 8 - ENATEC

Слика 8 - ENATEC

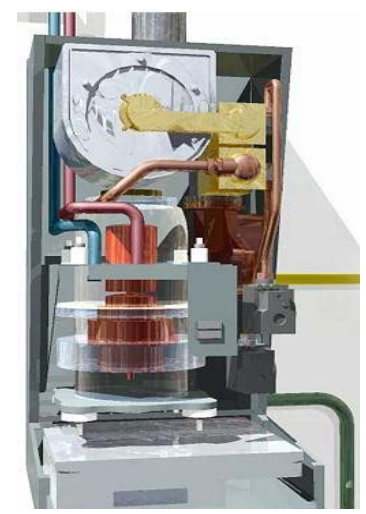

Figure 9 - The cross-section of the cogeneration plant, Microgen company Puc. 9 - Поперечное сечение когенерационной установки компании „Microgen» Слика 9 - Попречни пресек когенерационог постројења фрирме Microgen 
Steam turbines are not generally intended for use in small cogeneration plants, but are suitable for remote heating systems.

The Czech company TED produces a series of Micro-CHP plants that typically use natural gas as a fuel, but some have been modified to use biogas. There are eight models that use biogas $(<1 \mathrm{MWe})$, from a range of models from $23 \mathrm{kWe}(42 \mathrm{kWt})$ to $300 \mathrm{kWe}(370 \mathrm{kWt})$. These units have efficiency between 76 and $85 \%$ (Figures 10 and 11).

The units are designed to work with the content of methane between $55-65 \%$, but the absolute minimum is $50 \%$. The pressure in the combustion chamber is in the range from 1.5 to $10 \mathrm{kPa} .22 \mathrm{~kW}$ is scheduled for operation of 4,000 hours per year.

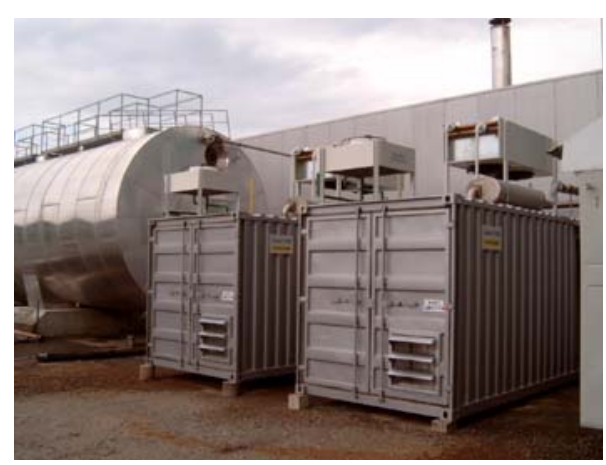

Figure 10 - Modlany, CZ, TEDOM Cento 150 SP BIO 150 kWe, 192 kWt Puc. 10 - Modlany, CZ, TEDOM Cento 150 SP BIO 150 kWe, 192 kWt Слика 10 - Modlany, CZ, TEDOM Cento 150 SP BIO 150 kWe, 192 kWt

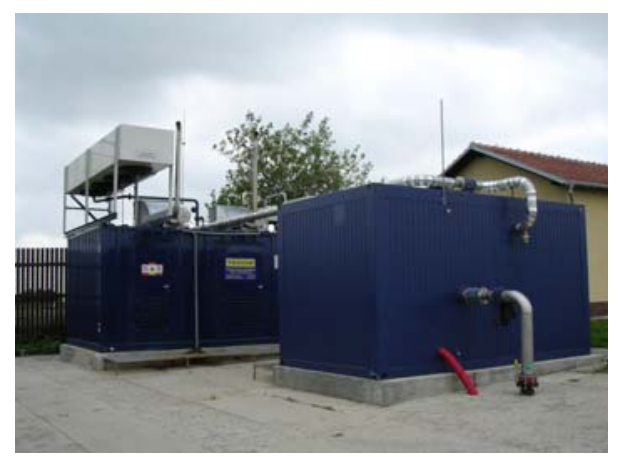

Figure 11 - Petruvky, CZ, TEDOM Cento T 300 SP 300 kWe, 370 kWt Puc. 11 - Petruvky, CZ, TEDOM Cento T 300 SP 300 kWe, 370 kWt Слика 11 - Petruvky, CZ, TEDOM Cento T 300 SP 300 kWe, 370 kWt 
BODERUS, from Belgium, produces Micro-CHP units (Figure 12) that use biogas and natural gas. Commercially available units are in a range of capacities from 10 to $383 \mathrm{kWe}$. For units using biogas, the minimum criteria for chemical composition of bio gas are set, primarily for a methane content of $80 \%$. These units achieve $94 \%$ efficiency and are designed to operate for 8,000 hours per year (Cummins Inc, 2014).

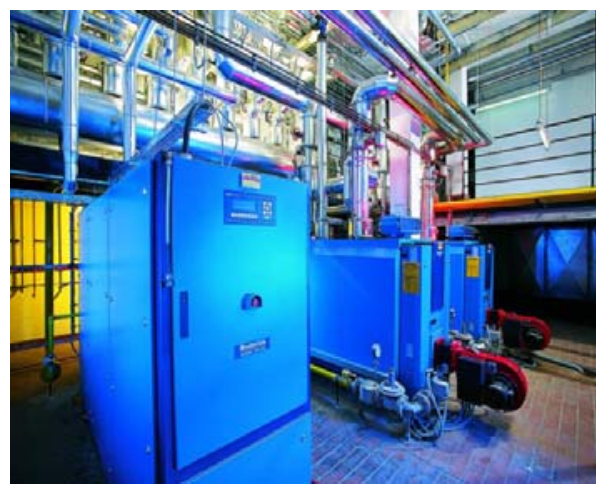

Figure 12 - BODERUS

PUC. 12 - BODERUS

Слика $12-$ BODERUS

The Italian ENERGIA NOVA company (Figure 13) produces small gas engines for CHP units of $20 \mathrm{kWe}, 47 \mathrm{kWt}$, based on the FIAT 1200 cc engine. The overall efficiency is $97 \%$ (29\% - electric power, $68 \%$ heat power). Maintenance is recommended after every 1,500 operating hours. NOx emission is very low. An ENERGIA NOVA report says that users can save up to $40 \%$ of fuel per year using this CHP system.

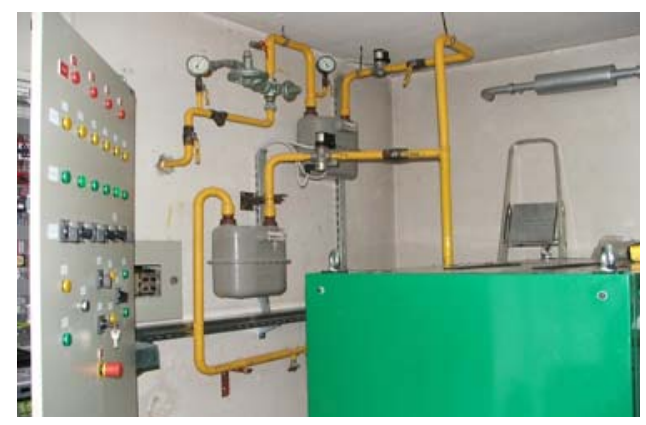

Figure 13 - ENERGIA NOVA

Puc. 13 - ENERGIA NOVA

Слика 13 - ENERGIA NOVA 


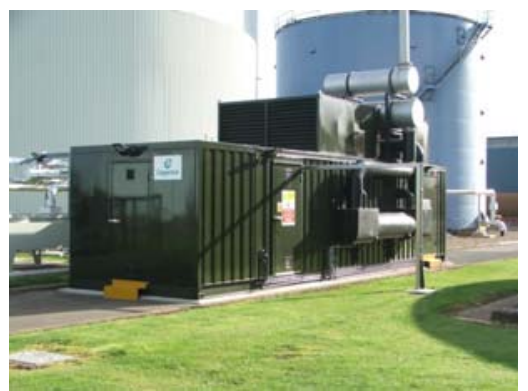

Figure 14 - COGENCO (300kWe)

Puc. 14 - COGENCO (300kWe)

Слика 14 - COGENCO (300kWe)

COGENCO (Figure 14), headquartered in the UK, produces and sells CHP biogas units. Cogeneration units are from 116 to $1750 \mathrm{kWe}$ and from 186 to $1,737 \mathrm{kWt}$.

TOPEC BV (Figures 15, 16), from the Netherlands, produces smallCHP biogas units from 100 to $1000 \mathrm{kWe}$. A TOPEC report states that fuel saving is about $30 \%$, and the overall efficiency is $90 \%$ (Cummins Inc, 2014).

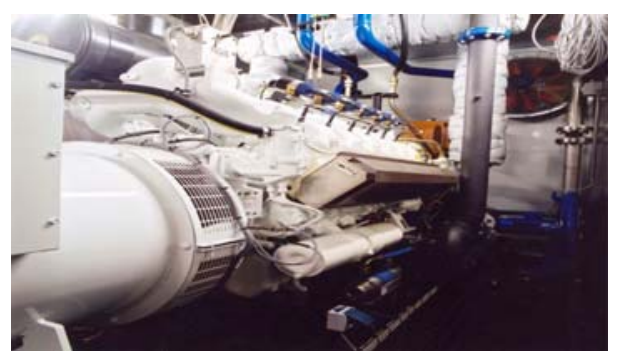

Figure 15 - TOPEC BV (190 kWe)

Puc. 15 - TOPEC BV $(190 \mathrm{kWe})$

Слика 15 - TOPEC BV (190 kWe)

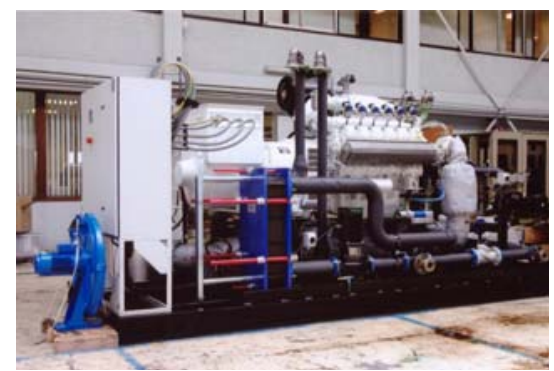

Figure 16 - TOPEC BV (340 kWe)

Puc. 16 - TOPEC BV $(340 \mathrm{kWe})$

Слика 16 - TOPEC BV (340 kWe) 
Techno-economic analysis of the application of CHP technologies

Investment costs for maintenance and costs of CHP technology and condensation boilers can be found in Table 1 (http://www.erec.org).

Table 1 - Investment and maintenance costs of CHP plants

Таблица 1 - Cтоимость инвестиций и содержания ТЭС

Табела 1 - Цене инвестиција и одржавања СНР постројења

\begin{tabular}{|l|l|l|}
\hline & Installation price $(€)$ & $\begin{array}{l}\text { The cost of maintenance } \\
(€ / \mathrm{y})\end{array}$ \\
\hline Senertec & 13750 & 100 \\
\hline Ecopower & 11750 & 100 \\
\hline Solo & 25000 & 75 \\
\hline Whispertech & 9000 & 75 \\
\hline Idatech & 140000 & 35 \\
\hline Condensing boiler & 2000 & 35 \\
\hline
\end{tabular}

A feasibility analysis is done for a QSK60 plant as an illustration, based on the existing prices of energy products (Zukić et al, 2005, pp. 259-262).

Table 2 - QSK60 Specification

Таблича 2 - Спецификация QCK60

Табела 2 - Специфокација QCK60

\begin{tabular}{|l|l|l|}
\hline Gas-generator set QSK60 & & $1.16 \mathrm{MWe}$ \\
\hline Annual exploitation & & 8000 sati \\
\hline The total investment & $500 € / \mathrm{kWe}$ & $580.000 €$ \\
\hline Operating and maintenance costs & & $7 € / \mathrm{MWhe}$ \\
\hline Electrical efficiency & $33-40 \%$ & $38 \%$ \\
\hline Thermal efficiency & $40-50 \%$ & $47 \%$ \\
\hline Gas prices & & $16 € / \mathrm{MWh}$ \\
\hline Heat versus gas costs & & 1.1 \\
\hline Price of electricity & $2,5 / 3,5$ & $36 € / \mathrm{MWh}$ \\
\hline The government initiative & $10 / 25 € / \mathrm{MWhe}$ & $0 € / \mathrm{MWhe}$ \\
\hline
\end{tabular}

Table 2 provides the input data and the plant costs (Zukić et al, 2005, pp. 259-262).

Table 3, on the one hand, shows the total cost of the exploitation by MWh of electricity produced, and, on the other hand, shows the costs of a classic, separate production. After about 5.5 years, the return on investment is completely achieved. Note that this is a facility meant to operate over 100, 000 hours (Said et al, 2005, pp. 259-262). 
Table 3 - Example of assessing the cost-effectiveness

Таблица 3 - Пример прогноза экономической эфрорективности Табела 3 - Пример процене исплативости

\begin{tabular}{|l|l|l|l|}
\hline Gas & $39.5 € / M W h e$ & Heat & $21.8 € / M W h e$ \\
\hline Service & $7 € / M W h e$ & Electric energy & $36 € / M W h e$ \\
\hline Back-up & $0 € / M W h e$ & Initiative & $0 € / M W h e$ \\
\hline Bonus & $46.5 € / M W h e$ & & $57.8 € / M W h e$ \\
\hline $\begin{array}{l}\text { The cost- } \\
\text { effectiveness } \\
\text { coefficient }\end{array}$ & $11.3 € / M W h$ & & $104.864 € /$ year \\
\hline $\begin{array}{l}\text { Period of cost- } \\
\text { effectiveness }\end{array}$ & $18.08 \%$ & & \\
\hline
\end{tabular}

Therefore, in addition to energy efficiency and environmental acceptability, small CHP plants are economically viable in the current circumstances. The government initiative can help to reduce the time and cost effectiveness to two or three years, because, in circumstances where care is taken of strategy of use of natural resources, clean and efficient technologies, this system is additionally subsidized for every $\mathrm{MWh}$ produced.

\section{Conclusion}

Micro cogeneration is a technology of the future. It will definitely find its wider application in Serbia if the Republic of Serbia decides to keep up with global energy trends. Creating favorable conditions for the realization of wider application would mean arranging legislative framework, desirable new forms of financing, and the price of electricity purchase should be included as well as environmental components.

CHP plants in Serbia could make three times more energy for heating, so the existing number of approximately 450,000 central heating customers could rise to more than one million. This would save $52 \%$ of primary energy and pollutant emissions would be reduced by $72 \%$ compared to the production of electricity from power plants and boiler heat.

Stirling engines as part of CHP plants have the best possibility of primary energy saving and $\mathrm{CO} 2$ emission reduction.

Solid biomass remains the main potential for a wide application for cogeneration systems at small and micro levels. The development of biogas supply systems should be developed to meet different 
requirements in terms of the chemical composition of biogas and its impurities. Gas originating from biomass and used in gas engines or gas turbines is another area of interest to small and medium-sized cogeneration plants. The Stirling engine combined with a pellet burner offers a solution that should be soon available.

\section{References}

Alanne, K., Laukkanen, T., Saari, K. \& Jokisalo, J. 2014. Analysis of a wooden pellet-fueled domestic thermoelectric cogeneration system. Applied Thermal Engineering, 63(1), pp.1-10. Available at: https://doi.org/10.1016/j.applthermaleng.2013.10.054.

-Cummins Inc. 2014. Available at: http://www.cumminspower.com. Accessed: 01.12. 2014.

de Paepe, M., D'herdt, P. \& Mertens, D. 2006. Micro-CHP systems for residential applications. Energy Conversion and Management, 47(18-19), pp.3435-3446. Available at: https://doi.org/10.1016/j.enconman.2005.12.024.

Despotović, M. \& Babić, M. 2007. Energija biomase. Kragujevac: University of Kragujevac - Faculty of Mechanical Engineering (in Serbian).

http://www.erec.org. Accessed: 01.12. 2014.

Pehnt, M., Cames, M., Fischer, C., Praetorius, B., Schneider, L., Schumacher, K. \& Voß, J.P. 2006. Micro Cogeneration: Towards Decentralized Energy Systems. [e-book]. Berlin Heidelberg: Springer-Verlag. Available at: http://www.springer.com/us/book/9783540255826. Accessed: 01. December 2014.

Rosato, A. \& Sibilio, S. 2013. Energy performance of a micro-cogeneration device during transient and steady-state operation: Experiments and simulations. Applied Thermal Engineering, 52(2), pp.478-491. Available at: https://doi.org/10.1016/j.applthermaleng.2012.12.028

Zukić, D., Stone, A. \& Cox, R. 2005. Mala kogenerativna postrojenja kao ekonomski opravdana, ekonomski efikasna, a ekološki prihvatljiva tehnologija. Energija, 2-3, pp.259-262 (in Serbian).

ПРИМЕНЕНИЕ МАЛЫХ И МИКРО-КОГЕНЕРАЦИОННЫХ УСТАНОВОК

Милан Р. Радосавлевич

Университет в г. Крагуевац, Инженерный фракультет,

Кафедра энергетики и технологических процессов,

г. Крагуевац, Республика Сербия

ОБЛАСТЬ: химические технологии

ВИД СТАТЬИ: профессиональная статья

ЯЗЫК СТАТЬИ: английский 
Резюме:

До 1973 года низкие цены топлива позволяли производство относительно недорогой электроэнергии. Однако резкий рост цен на топливо привел $к$ разработке новых энергетических технологий $и$ к повышению эфрорективности установок. Одновременно, повышение экологической осведомленности, в том числе $u$ осознание проблемы исчерпаемости природных энергоресурсов, требовали повышенного внимания к охране окружающей среды и оставшихся ресурсов, таким образом малые и микро-ТЭЦ стали конкурентоспособными и более востребованными в области энергопромышленности. США и Канада на сегодняшний день в этом плане отстают от европейского и японского развития микрогенерации, частично изза различий в системе отопления, стоимости электроэнергии и в связи с политическими рамками. Подписанием Киотского протокола, Япония обязалась сократить воздействие на глобальное потепление, то есть, выбросы на 6\% от общего уровня выбросов за 1990 год. Однако уровень выбросов СО2 все еще продолжает расти, а это значит, что в настоящее время Япония для достижения своей цели должна сократить выбросы на 14\%. В данной связи Япония пропагандирует все возможные способы эфрфективного снижения выбросов СО2. Япония будет активно продолжать поддерживать маркетинг микрогенерации, особенно модели, подходящие для отопления жилых зданий. Прогнозируется, что в ближайшие несколько лет в Европе производство электроэнергии с помощью когенерации достигнет $75 \%$ om общего объема производства в целом. Так, например, в Италии производство возобновляемой энергии составляет 30\% от общего объема потребления; в Нидерландах - 33\%; а Дания и Великобритания почти полностью перешли на данный вид энергопроизводства.

Ключевые слова: микро-когенерация, малые ТЭЦ.

\section{ПРИМЕНА МАЛИХ И МИКРОКОГЕНЕРАЦИОНИХ ПОСТРОЈЕЊА}

Милан Р. Радосављевић

Факултет инжењерских наука, Катедра за енергетику и процесну технику, Крагујевац

ОБЛАСТ: хемијске технологије ВРСТА ЧЛАНКА: стручни чланак ЈЕЗИК ЧЛАНКА: енглескИ 


\section{Сажетак:}

До 1973. године ниске цене горива омогућавале су производњу релативно јефртине електричне енергије. Нагли пораст цена горива изазвао је потребу за развијањем енергетских технологија и повећањем ефикасности постројења. Истовремено, повећана еколошка свест, као и сазнање о све сиромашнијим изворима енергије, захтевало је посвећење веће пажње очувању околине и преосталих ресурса, па су мала и микрокогенерациона постројења постала ефикасни и конкурентни произвођачи енергије. Сједињене Државе и Канада тренутно су у заостатку у односу на развој европских и јапанских микрокогенерација, делимично због разлика у системима грејања, цене енергије и политичких оквира. Кјото протоколом Јапан је у обавези да смањи своје глобално загревање, односно емисију гасова за 6\% од нивоа из 1990.године. Ипак, емисија $\mathrm{CO}_{2}$ и даље расте. Процењује се да Јапан мора да смањи емисију за 14\% како би испунио циљ, као и да промовише све могуће начине да ефрикасно смањи емисију $\mathrm{CO}_{2}$. С тим у вези, Јапан ће наставити да даје подршку маркетингу микрокогенерације, посебно оних модела који су погодни за стамбене објекте. Процењује се да у неколико наредних година производња енергије когенерацијом достигне 75\% укупне производње на нивоу целе Европе. Еколошка енергија у Италији чини 30\% укупне потрошње, у Холандији 33\%, а у Данској и Великој Британији готово је потпуно заступљена.

Кључне речи: микрокогенерација, мала когенерација.

Paper received on / Дата получения работы / Датум пријема чланка: 10.12.2014. Manuscript corrections submitted on / Дата получения исправленной версии работы / Датум достављања исправки рукописа: 10.11.2017.

Paper accepted for publishing on / Дата окончательного согласования работы / Датум коначног прихватања чланка за објављивање: 12.11.2017.

(C) 2018 The Author. Published by Vojnotehnički glasnik / Military Technical Courier (www.vtg.mod.gov.rs, втг.мо.упр.срб). This article is an open access article distributed under the terms and conditions of the Creative Commons Attribution license (http://creativecommons.org/licenses/by/3.0/rs/).

() 2018 Автор. Опубликовано в «Военно-технический вестник / Vojnotehnički glasnik / Military Technical Courier» (www.vtg.mod.gov.rs, втг.мо.упр.срб). Данная статья в открытом доступе и распространяется в соответствии с лицензией «Creative Commons» (http://creativecommons.org/licenses/by/3.0/rs/).

(c) 2018 Аутор. Објавио Војнотехнички гласник / Vojnotehnički glasnik / Military Technical Courier (www.vtg.mod.gov.rs, втг.мо.упр.срб). Ово је чланак отвореног приступа и дистрибуира се у складу са Creative Commons licencom (http://creativecommons.org/licenses/by/3.0/rs/).

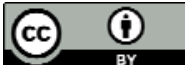

